\title{
Achievement Motivation and Its Relationship with Characteristics of Leaders in Youth Centers in Jordanian Society
}

\author{
Dr. Safia Jabali \\ Associate professor, Department of education \\ Zarq'a University, Jordan
}

Received: Jan 26, 2016 Accepted: Feb. 5, 2016 Published: February 5, 2016

doi:10.5296/jse.v6i1.8244 URL: http://dx.doi.org/10.5296/jse.v6i1.8244

\begin{abstract}
This study aimed to detect achievement motivation and its relationship with the members of The Leader features youth centers in Jordanian society. Where the study sample consisted of 638 young men and women of the members of the youth centers in the Kingdom of them (366) and a young man (272) were chosen young intentional way of participating in the Ajloun and cypress camps during 2014. The researcher used a special test designed to measure the effective leader attributes and test achievement motivation and who has been verified sincerity and the Calendar researcher used the averages, standard deviations, and percentages, and transactions of the link and test $(\mathrm{g})$, and testing of regression analysis and found the results to the existence of a positive relationship between characteristics social, personal and administrative effective leader as perceived by members and achievement motivation they have at the significance level $(\alpha \leq 0,05)$. And the lack of statistically significant differences in the relationship between the characteristics of an effective leader differences as perceived by members and achievement motivation at the significance level $(\alpha \leq 0,05)$ attributable to differences between the sexes. The study also recommends that workers leaders working with young people to raise achievement motivation among members through enhance the behavior of interest. And provide a democratic atmosphere for members in matters of activities and decisions and others. Holding training courses and programs for the rehabilitation of leaders working with young people.
\end{abstract}

Keywords: achievement motivation, the leaders, youth centers, the Jordanian society. 


\section{Introduction}

The youth centers in Jordanian society increasingly important may constitute the basic building block in the preparation of a prominent balanced generation works on the development and construction of the homeland, State on the support of the Supreme Council for young people to play a prominent role in the preparation and refinement and development of young people's character and strengthens the same service and society. The oversight actor on youth centers multiple dimensions, and vary effectiveness depending on the leaders in terms of traits and abilities and programs that they might, it was found that general mental ability of the commander of the training and programs that are subject to it, the process and its potential, and his motives are all factors that lead to success, and this is therefore reflected in the associate, Given the role of wrought commander in associate, which is complementary to the role of the teacher in the school through give participants the knowledge, skills and attitudes through the programs offered by the youth center, emanating from the young people's needs and desires and what They must have its values and principles, and the extent to which the center of those goals desired from those programs.

\section{Problem of the study}

The problem with the study researcher in a note some of the obstacles and pitfalls such as the weakness of the administrative and technical capacity of the majority of the cadres of youth centers in Jordan, which is an obstacle to any development in programs and youth activities. Predicts researcher through briefed on the reality of youth centers that there is a relationship between the leaders of the youth centers and achievement motivation for the members and that the assessment is based on the quality of the activities and programs offered by the commander of the members and to the strength of the interaction between leaders and members on the one hand and members with each other on the other hand that. So study the problem emerged in the detection of the most important features to be met by the commander from the point of view of members and reflected on the achievement motivation they have.

\section{Study questions}

1. What achievement motivation and its relationship with characteristics of leaders of youth centers in a sample of members of the youth centers in Jordan have?

2. There were statistically significant relationship between achievement motivation to the commander attributes with young people in the social sphere, and personal, and administrative as perceived by members?

3. There were no statistically significant differences in the relationship between the commander achievement motivation attributes differences with young people due to the variable sex?

4. There are predictive ability of the characteristics of the leader factor in young centers in the prediction of the degree of achievement motivation members? 


\section{Importance of the study}

The youth centers are the primary tributary of the main booster of the Supreme Council for Youth through its philosophy to promote the ideas of the youth home and develop their skills and refine their personality, is the study of important studies being shed light on the importance of achievement motivation and its relationship with characteristics of leaders in youth centers. It is one of the rare studies in Jordan, which touched on this Modua.kma expected to benefit from the Supreme Council for Youth and leaders of youth centers, and that the results of this research have many educational applications, it strengthens the impact and the role of commander in achieving education goals or achieve the objectives of learning and overall education process and alerting workers in the education sector and the youth sector to the need to integrate the efforts of the two parties in the student's personal or organ development and thus achievement motivation, which is expected to be positively reflected on his performance in schools and youth centers development.

\section{The study determinants}

The sample in this study was limited to a group of members of the youth centers involved in youth gatherings organized by the Higher Council for Youth in Jordan during the 2014/2015 academic year

\section{Procedural definitions}

Attributes commander worker with young people: a set of required features available in the commander, and show through behaviors practiced toward associated, measured mainly obtained by the commander on the list of paragraphs effective leader, which is considered one of the two tools study attributes.

Achievement motivation: a desire to achieve a good performance, and complete the work efficiently, which is the goal of a self-activate and directs behavior, and achievement motivation is measured by the degree to which obtained by the commander on the paragraphs of the private measure achievement motivation in this study.

\section{The theoretical framework and previous studies}

The interest in youth is no longer a local or regional phenomenon but has become a global phenomenon, and have a distinct role in the development process support . The deal with young people is an investment project in the long run. To the extent that we give young people and kiss him to the extent that a generous payoff in the form of constructive human experiences contribute to the preparation of leaders, which has become the right age is wealth and power parameters and excellence in the world of the cognitive revolution. the interest in youth, and concern for the upbringing, and educate them, teach them, has become one of the priorities of development plans, in order to grow in a healthy atmosphere to enable them to participate effectively in the advancement of their communities, and to maintain the entity of their nation, and the leadership of this stage groups became one of the first concerns of researchers from psychologists, education, and the meeting. Especially in the era of early young adulthood, the young people at this stage in the beginning of maturity. They are in dire 
need for educational programs, and educational, and entertainment, as well as the urgent need for the leaders of a successful understands ages and requirements attributes, in order to guarantee them mature properly targeted stems from a collective sense, and deepen in them the sense of belonging to a society that places them high expectations to build the edifice, and offer $\mathrm{f}$ came Supreme Council for Youth philosophy to work on the preparation and organization of targeted programs, working to take care of Jordanian youth and creative investment leisure what is good and beneficial through bodies and youth centers.

Little Sour $(21,1981-29 s)$ that the leading role of the commander of the youth is one of the main pillars in the youth care, and guidance, and that young people guidance process you need to coach with educational and social experience to achieve social harmony among young people and create a common thought and trends in unified them in order to boost work collective and constructive cooperation, although the youth leader is supportive of the family, in terms of guiding young people and work on forming positive behaviors they have it faces the same types of problems faced by the parent. It is useful that the commander encouraged to project young people a sense of independence in their lives, using the means of persuasion successful development and mentions several functions carried out by the commander in order to contribute to the cohesion of the installation of the group, and accomplish and achieve the goals: administrative port, and planned, and author of the policy of the institution, and expert, and representative external to the group, and internal relations officer, and a source of reward and punishment, such as model or higher, and a symbol of the group and the image of the father.

It is noteworthy single (2001, 201-203s) The social psychologists stress the importance of leadership, and the significant role it plays in building different groups, and the commander of great importance in the cohesion of the group, and its objectives. that there are a range of features of the behavior of the leadership has to be ownership The interaction and social activity, and integration, planning, order and organization, initiative, ambition, control, and courage, and compatibility psychological and social, and the representation of the group's other groups, and self-confidence, and sensitivity to the feelings and empathy emotional, and tolerance, and the mind of the group, and taking into account individual circumstances.

Refers Reedet (Reedet, 1993,76-79) The attributes of an effective leader accomplish the tasks entrusted to him by the group led by. It is seen as an effective leader done for the organization's goals or body, and satisfy the needs of the community and contribute to the well-being in the near term, and long body in which it operates. In the eyes of Heath (Hith, 1988,107) The effective leader is a person who has the ability to see or imagine what will be the future of the organization, and has at the same time the ability to translate these concepts into action meaningful or always trying to change.It is noteworthy highway (23.1999) The commander of the youth is a professional leader in youth and sports field, where the areas of youth care has become one of the professions President, which requires to take over the functions of those areas leaders specialize, to oversee the organization and management of youth and sports systems and core functions of the commander professional actor:

1. supervising the organization of sports and youth programs in youth bodies. 
2. The organization of courses and lectures on the importance of volunteer work, and dissemination of media awareness of the services provided by the youth activities of the individual and society.

3. work to create opportunities for exercise, and recreational programs, social, technical and scientific in order to invest leisure time young people are important and constructive activities.

It is noteworthy agitation (1993.35-7) The personality of the individual, whether a leader or a subordinate affect his relationship with others, and in the performance of the organization, and knowledge of building personal or self is necessary for the leader, by virtue of the responsibilities for the success or the organization that employs failure. And expresses Shane (schein, 1988, 33p) essential core of values in leadership, and that arise through social normalization, which are considered leaders the values of an impact on the performance and functioning of the organization, every commander is influenced by a range of values such as achievement, and quality of services provided, and maintain at the time, and justice in the interaction, and to follow the official formulas in dealing and competition.

The Sarhan good (73.2000) they added that there is a moral basics of leadership to work with young people:

1. Is young as they are, in fact, not as they should be; and respect that would be regarded as a full self emotion, and makes them feel that they have dignity and entity. Thus able commander or leader of youth absorption feelings of inferiority felt by young people. And acceptance also means concern for them in terms of their preferences and desires and aspects of their activities and guiding the correct destination, and through this receptivity arise intimacy between the leader or youth leader who cares about youth withal without discrimination regardless of their beliefs and ideas relationship, and must provide the desire of the commander assistance and guidance without it.

2. self-directed, which means giving young people the freedom to make the appropriate decisions for their own good, and involve them in bearing the greatest burden of the responsibility of directing their lives present and future

3. listen to the needs of young people.

I've mentioned Likert (likert, 1980,51) that managers and leaders of the youth sections and other departments have achieved productive and tender was high by following these behavioral patterns:

A) human-interest aspects in solving the problems they face with Members or between Members.

B) advice between them and their subordinates about work issues and programs.

C) interest in the affairs associate through identifying their problems, their desires, and motivations.

D) evaluation of activities collectively.

He adds Gray and Stark (Gray \& starke, 1980, 346p) to successful or effective leader attributes: Be characterized humanity, good morals, good general appearance, and respect for 
the institution laws in which it operates, which is reflected on the achievement associate, and investigating themselves in various aspects.

\section{Previous studies}

The Dickson (Dickson, 1994) entitled studying the impact of the handling by the commanders on the achievement motivation among employees of youth centers in Britain, ranging in age from 13-16 years old. The researcher used a special test trends and test a special achievement motivation. The results showed that the leaders and members of women leaders who are treated in a manner less aggression, and violence, and neglect, and discrimination Members be more capable of achievement and success, and that reward excellence and plays better than punishment role in raising achievement motivation when participants.

He also Cornell (Cornell, 1996) studied in Canada entitled social behaviors and decision-making to the commander of the successful Youth and Sports, which aimed to determine the necessary features of the commander of the successful youth and sports, in Canada. The results of the study to the following features: human skill in his behavior, his relationship with his subordinates, his self-confidence and ability to deliver, its ability to develop individuals and what takes it from his knowledge of his subordinates and their ability, and energy, and the possibility of training and development, and his belief in the value of teamwork, and self-restraint, and integrity and honesty.

Study Momani (2005) entitled determine the level of the relationship between achievement motivation and locus of control with graduate students at the Faculty of Education at Yarmouk University in Jordan and study aimed to know the relationship between achievement motivation and MKZ setting when you graduate students and the population of the study (910) students of his request graduate enrolled for the academic year (2005) The study sample consisted of (250) students. The researcher developed achievement motivation scale and the use of the center of the center to adjust to the scale prepared by Barhoum (1979) to fit the environment of Jordan and the results showed the presence of medium to achievement motivation among graduate students and the lack of significant differences in achievement motivation due to gender, specialization and educational qualification.

Enhanced study (2006): entitled self-efficacy perceived and their relationship motivation achievement and compatibility and achievement among a sample of students of the Faculty of Education at the University of Yarmouk and the purpose of this study to detect the level of self-efficacy perceived and their relationship motivation achievement and compatibility and achievement in the light of their specialization and their sex and their level of academic was used self-efficacy scale perceived, and the measure of achievement motivation and scale compatibility for college students and study sample consisted of 154 students from the bachelor's level and the results were that the vast majority of the members of the study sample in the level of self-efficacy perceived medium and that all variables (achievement motivation and compatibility and collection) interpreted the variation in the level of self-efficacy perceived. Where these variables together was able to explain what percentage of $(68.7 \%)$ of the variation in the level of perceived self-efficacy. The results revealed that more variables in the ability to predict the level of perceived self-efficacy variable was the 
night in a collection that consensus variable and variable achievement motivation comes ranked the last.

Study Dalalhh (2006) entitled determine the level of achievement of secondary schools and government students of Arabs and Jews in the Galilee region on the school type variables (Jewish-Arab) and sex (male female) and branch academic (scientific literary) The study aimed to determine the level of achievement at the Komi high school students from Arabs, Jews and study sample consisted of 786 students and asked him to any $10 \%$ of the study were community (524) students from schools in Arabic and (262) of Jewish schools distributors on (19) high school (14) School Arabic and (5) Schools Jewish and the researcher developed a measure of achievement motivation Arabic, Hebrew and the results of the study that the level of achievement motivation at secondary school students in the area Lower Galilee is located within the mid-level, where the average level year amounted to measure achievement motivation (100.20) and show a statistically significant differences between Arab schools and Judaism in motivation achievement for the benefit of Arab schools and between males and females in achievement motivation in favor of females.

The results of previous studies that leadership is one of the most important phenomena of social interaction, and that the leaders who played a key role in understanding the influence in guiding the group activity, and the extent of interdependence, and the spirit prevailing among its members and associate achievements. She also noted some leadership qualities to be met by the successful youth leader. But they did not reach a specific recipes can pivot in determining the personal qualities of successful leadership. It is also noted from the results of some studies to a strong relationship between many of the qualities of the leader of youth and achievement motivation, but this current study characterized as other that it focused on the attributes of an effective leader in the administrative, social and personal areas and its impact on achievement motivation, in addition to that they have developed a special measure for measure attributes of an effective leader from the point of view of members and their ability to predict in achievement motivation among Members on the new Jordanian sample.

\section{The method and procedures}

\section{Study Approach}

It was used descriptive method survey manner to suit them with the nature of the study.

The study population:

The study population consisted of all associate centers for youth in Jordan consists. Who number (7243) of them (4233) and male (3010) female. The number of centers amounts of (76) Seventy-six centers including: (31), one for females and thirty (45) Forty-five for males. The study sample:

It was selected sample of the study purposely, and consisted of (683) young men and women of them (366) males and (272) young participants in youth gatherings hosted by the Higher Council for Youth on the camps of Ajloun and cypress, within the age group (15-18 years) and shows Table (1) the distribution of eye members. 
The distribution of the study sample by gender and provinces

\begin{tabular}{|l|l|l|}
\hline Conservatism & $\begin{array}{l}\text { The number of female members } \\
\text { of the sample }\end{array}$ & $\begin{array}{l}\text { The number of male members of } \\
\text { the sample }\end{array}$ \\
\hline Alzarqa'a & 17 & 50 \\
\hline Madaba & 21 & 16 \\
\hline The capital & - & 7 \\
\hline Salt & 42 & 37 \\
\hline Mafraq & 35 & 61 \\
\hline Ajloun & 11 & 17 \\
\hline Jerash & 10 & 15 \\
\hline Ma'an & 41 & 50 \\
\hline Karak & 43 & 14 \\
\hline Tafila & 27 & 37 \\
\hline Aqaba & 7 & 22 \\
\hline Irbid & 18 & 40 \\
\hline Total & 272 & 366 \\
\hline
\end{tabular}

\section{Tools of the study}

In this study, the following instruments:

First: Commander worker attributes scale with young people:

It has been building scale through the return of the researcher to the educational studies in the field of leadership and management as well as social studies and access to study tools used in these studies, as well as the views of specialists in youth work were obtained ten paragraphs in line with the objective of the study and are directly related to characteristics of the leader of youth, after that the face of the researcher an open question for a number of Associate of youth centers in Jordan, the participants in the rally members Promising Leaders organized by the Supreme Council for Youth, totaling (98) Ninety-eight participants and participation. Where the question was: What behaviors of practice before an effective leader and that seefrom your point of view - the need to possess and practice have, to his knowledge effectively and the success?

I have been given a period of time of ten minutes to answer this question, and during that period has to answer participants' questions, and after receiving the answers, the researcher empty it. Similar responses were collected in secured and drop the responses is consistent with the objective of the study nine answers and guestrooms, and drop the responses with low frequencies not exceeding ten iterations eight vertebrae and guestrooms. When it was obtained (48) Forty-eight response consistent with the objective of the study, until it became total, the initial paragraphs of its image and fifty eight paragraph, spread over three areas: personal, social and administrative.

\section{Believe scale}

Paragraphs offered on a group of leaders of experienced and competent in order to give their comments on it. In terms of formulation and suitability, and its ability to measure the 
attributes of an effective leader, and after gathering tool was introduced their observations, have been installed paragraphs, and reformulated until noon measure in its final form consisting of forty-five paragraph.

\section{The stability of the scale}

Stability refers to the degree to which the work including the measure to give the same results as measured repeating the same things (Humsi, 1991, 25) In order to test the stability according to this method was applied to the author of a sample of 45 affiliate centers Youth, and two weeks after the first application re-test the same group and using the Pearson correlation coefficient application

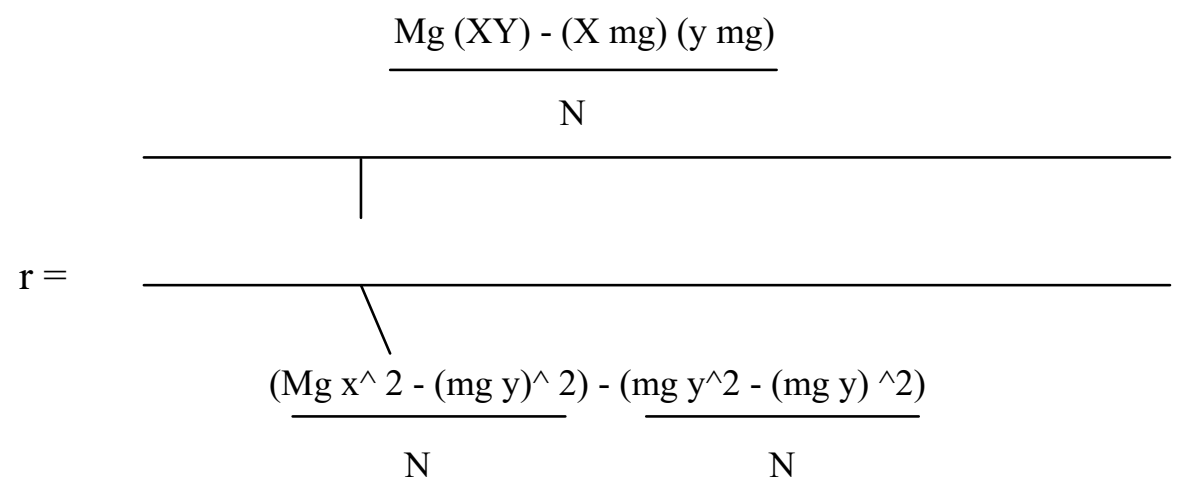

It shows the link between the two choices plant

\begin{tabular}{|l|l|l|}
\hline No & Side & Young plant \\
\hline 1 & Social & 0.09 \\
\hline 2 & Profile & 0.91 \\
\hline 3 & Administrative & 0.90 \\
\hline 4 & Total & 0.90 \\
\hline
\end{tabular}

The researcher also calculates the reliability coefficient and a second way of equation Cronbak "Alpha" as an indicator of the internal consistency of the scale where:

Alpha $=\frac{\mathrm{n}}{\mathrm{n}-1} \quad \frac{\left(1 \mathrm{mg} \mathrm{p}^{\wedge} 2 \mathrm{k}\right)}{\mathrm{p}^{\wedge} 2}$

Where the result indicated that the scale enjoyed by a factor of stability and the ability of (0.92).

Scale correction:

The scale of forty-five paragraph consists, so that the participant for each paragraph answer by his conviction by choosing one of the five alternatives, and follow in the way of estimating grades in this tool following the staging: (4) Alternative always (3) alternative often (2) of the alternative Sometimes (1) of the alternative rarely (0) never substitute for. Thus, the total score of the scale ranging between (zero - 180).

Second, measurement of achievement motivation 


\section{Macrothink}

I have used in this study, which was prepared by the scale Alababinh (1999), and consists of twenty-scale paragraph is included on the scale of five. The student answers each paragraph by choosing one of the alternatives very high degree, high, medium, low, very low, as shown in Annex (1).

The stability of the scale:

To ensure the stability of the scale test was applied and re-applied to a sample of the members of the non-sample of (45) forty-five members and was the period of time between the test application and re-apply two weeks, then their correlation coefficient was calculated and found to be equal to (0.89). Has also been used Cronbach's alpha coefficient as an indicator of the internal consistency of the test by applying the test on the experimental sample above, the results have shown that the test has a factor of stability of $\$(0.89)$.

Scale correction:

Achievement motivation scale consists of (20) items. Which (9) is positive and paragraphs (11) negative paragraph, included by way of staging Likert Quintet, depending on the degree of approval and are as follows:

Very high $=5,4=$ high, medium $=3,2=$ low, very low $=1$. So that the participant for each paragraph by choosing one of the alternatives mentioned above answers are calculated class by giving weights (5) of the alternative very high degree, (4) the alternative high degree, (3) the alternative moderately, (2) the alternative low-grade, (1) for alternative low-grade too, and in the case of paragraphs positive, and reflect the weights in the case of negative paragraphs.

\section{The study variables}

1- independent variables: personal attributes of an effective leader, and social and administrative.

2- intermediate variables: Gender: male, female.

3- dependent variables: achievement motivation when members.

Statistical treatment

To answer the study questions were arithmetic mean calculation, standard deviations, and correlation coefficients, and testing $(\mathrm{g})$ and analysis of the responses Members statistical regression on two scales in order to analyze the results of the study.

\section{View Results}

First, the results relating to the first hypothesis:

Provided on the first hypothesis is: no statistically significant relationship between the leader working with the youth in the social sphere, and personal and administrative features, and achievement motivation as perceived by members. We have been using averages, standard 


\section{Macrothink}

deviations, and Pearson correlation coefficient for each area of study, as shown in the tables No :(3, 4.5, 6).

- The social sphere

Table averages and standard deviations of the responses of respondents to the paragraphs of the commander working with young people in the social field attributes gauge shows rank in descending order

\begin{tabular}{|l|l|l|l|}
\hline No & Paragraph & $\begin{array}{l}\text { average } \\
\text { figure }\end{array}$ & $\begin{array}{l}\text { Arithmetic } \\
\text { standard deviation }\end{array}$ \\
\hline 1 & is estimated Members discerning and reinforced by & 3.56 & 0.71 \\
\hline 2 & $\begin{array}{l}\text { estimated the successful work carried out by } \\
\text { members }\end{array}$ & 3.45 & 0.84 \\
\hline 3 & \multicolumn{1}{|c|}{ respects human rights and duties } & 3.21 & 0.96 \\
\hline 4 & enjoys good relations with Members and their parents & 3.19 & 1.12 \\
\hline 5 & $\begin{array}{l}\text { Members enhances the positive behavior } \\
\text { commensurate with each one of them }\end{array}$ & 3.17 & 0.97 \\
\hline 6 & $\begin{array}{l}\text { provides an opportunity for members to express } \\
\text { themselves freely through the exercise of activities }\end{array}$ & 3.06 & 1.06 \\
\hline 7 & $\begin{array}{l}\text { consolidates the spirit of cooperation between } \\
\text { individuals and groups }\end{array}$ & 3.05 & 1.19 \\
\hline 8 & to exchange experiences with other leaders & 2.99 & 1.22 \\
\hline 9 & regulates social relations inside the center and outside & 2.95 & 1.15 \\
\hline 10 & $\begin{array}{l}\text { has an effective and persuasive communication skills } \\
\text { in order to communicate humanitarian }\end{array}$ & 2.94 & 1.14 \\
\hline 11 & Members encourage inactive & 2.73 & 1.38 \\
\hline 12 & $\begin{array}{l}\text { wearing an outfit that fits with the nature of the } \\
\text { activity in the center }\end{array}$ & 2.70 & 1.15 \\
\hline 13 & to submit proposals to serve the local community & 2.67 & 1.16 \\
\hline 14 & $\begin{array}{l}\text { connects the importance of environmental activities } \\
\text { and social problems in the local community }\end{array}$ & 2.52 & 1.28 \\
\hline 15 & Social sphere as a whole & 3.00 & 0.87 \\
\hline & & \\
\hline
\end{tabular}

Great brand (4)

Evidenced by the private social tags results the previous table that the first paragraph, which stipulates "Members discerning and reinforced by an estimated", received the highest average arithmetic was (3.56) with a standard deviation (0.71), then got paragraph (2), which stipulates " estimated the successful work carried out by members "to second place with a mean (3.45) and a standard deviation (0.84) came and paragraph number (14) in last place, which stipulates" the importance of linking the activities of environmental and social problems in the community "with an average My Account (2.52) with a standard deviation of (1.28). 


\section{Macrothink}

Table averages and standard deviations of the responses of respondents to paragraphs commander working with young people in the field attributes gauge shows the personal rank in descending order.

Paragraph number arithmetic average standard deviation

\begin{tabular}{|l|l|l|l|}
\hline No & Paragraph & $\begin{array}{l}\text { average } \\
\text { figure }\end{array}$ & $\begin{array}{l}\text { Arithmetic standard } \\
\text { deviation }\end{array}$ \\
\hline 1 & . respected his work and it belongs & 3.49 & 0.19 \\
\hline 2 & $\begin{array}{l}\text { express what he wants to clearly and } \\
\text { accurately }\end{array}$ & 3.48 & 0.80 \\
\hline 3 & . calm and restraint & 3.43 & 0.70 \\
\hline 4 & $\begin{array}{l}\text { listens caused when one of the members their } \\
\text { wishes }\end{array}$ & 3.28 & 1.02 \\
\hline 5 & $\begin{array}{l}\text { honesty and sincerity in dealing with } \\
\text { Members }\end{array}$ & 3.26 & 1.05 \\
\hline 6 & enjoyed himself with high confidence & 3.25 & 0.91 \\
\hline 7 & enjoyed himself with high confidence & 3.10 & 1.02 \\
\hline 8 & speaks loud and clear and understandable & 3.09 & 1.07 \\
\hline 9 & be patient and flexibility & 3.08 & 1.05 \\
\hline 10 & trusts the capabilities of Members & 3.05 & 1.02 \\
\hline 11 & $\begin{array}{l}\text { respectful of the views of Member and } \\
\text { suggestions }\end{array}$ & 2.93 & 1.09 \\
\hline 12 & amends in his dealings with members & 2.71 & 1.10 \\
\hline 13 & $\begin{array}{l}\text { General behavior represents a role model for } \\
\text { members }\end{array}$ & 1.66 & 0.47 \\
\hline & Domain Profile total & 3.17 & 0.67 \\
\hline
\end{tabular}

Great Relationship (4)

Is evident from the private tags results Personal previous table that the first paragraph, which stipulates: "respects his work and it belongs" received the highest average arithmetic reaching (3.49) with a standard deviation (0.91) followed by the second paragraph, which stipulates: "expresses what he wants to clearly and accurately "a mean of \$ (3.48) and a standard deviation (0.80) and it came third paragraph ten, which stipulates as:" general behavior represents a role model for members in last place with a mean of (1.66) with a standard deviation (0.47) Administrative -domain.

Averages and standard deviations of the responses of respondents to the paragraphs of the leader with the youth worker attributes scale in the management side in descending order. 
Paragraph number arithmetic average standard deviation

\begin{tabular}{|l|l|l|l|}
\hline No & Paragraph & $\begin{array}{l}\text { average } \\
\text { figure }\end{array}$ & $\begin{array}{l}\text { Arithmetic } \\
\text { standard deviation }\end{array}$ \\
\hline 1 & $\begin{array}{l}\text { Members are encouraged to take responsibility and } \\
\text { motivates them for the better }\end{array}$ & 3.46 & 0.83 \\
\hline 2 & $\begin{array}{l}\text { take into account the factors of security and safety } \\
\text { during the application activities }\end{array}$ & 3.40 & 0.77 \\
\hline 3 & encourages creativity and innovation & 3.37 & 0.86 \\
\hline 4 & $\begin{array}{l}\text { contribute to the development of personal User } \\
\text { through involvement in activities }\end{array}$ & 3.19 & 0.76 \\
\hline 5 & continuous presence in the center & 2.99 & 0.78 \\
\hline 6 & respects the laws and regulations for the activity & 2.98 & 0.47 \\
\hline 7 & watching the behavior of members and watched by & 2.96 & 0.75 \\
\hline 8 & diversifies in the sports, cultural and social activities & 2.95 & 0.56 \\
\hline 9 & $\begin{array}{l}\text { serves to provide the means and the necessary facilities } \\
\text { for the activities of members }\end{array}$ & 2.94 & 0.87 \\
\hline 10 & $\begin{array}{l}\text { coordinate with members to determine the appropriate } \\
\text { times for activities }\end{array}$ & 2.92 & 0.74 \\
\hline 11 & take appropriate decisions & 2.91 & 00.81 \\
\hline 12 & applied activities in the specified time & 2.87 & 0.54 \\
\hline 13 & $\begin{array}{l}\text { allow members to participate in activities appropriate } \\
\text { to their desires and abilities without discrimination }\end{array}$ & 2.85 & 0.72 \\
\hline 14 & $\begin{array}{l}\text { involve members in the planning of programs on the } \\
\text { center's activities }\end{array}$ & 2.75 & 0.76 \\
\hline 15 & $\begin{array}{l}\text { delegate part of his powers to members during } \\
\text { activities }\end{array}$ & 2.73 & 0.67 \\
\hline 16 & the ability to provide constructive feedback & 2.72 & 1.02 \\
\hline 17 & . Members recognize the needs and work to meet them & 2.61 & 0.52 \\
\hline 18 & Members recognize the problems and work on them & 2.48 & 0.72 \\
\hline & Administrative area total & 2.92 & 0.81 \\
\hline & & \\
\hline
\end{tabular}

Great brand (4)

Evidenced by private administrative tags results the previous table that the first paragraph, which stipulates: "Members are encouraged to take responsibility and motivates them for the better" has ranked first with a mean of (3.46) with a standard deviation (0.83), and comes second paragraph, which states to "take into account the security and safety factors during application activities" with a mean of \$ (3.40), and a standard deviation (0.77). And replaced ten eighth paragraph, which states: "Members recognize the problems and work on them," ranked last with a mean of $\$(2.48)$ and a standard deviation $(0.72)$.

The correlation coefficient between personality traits, social and administrative illustrates the commander worker with young people as perceived by members and achievement motivation they have. 
The value of the correlation coefficient number field level statistical significance statistically significant at the level of significance $(a \leqslant 0,05)$

\begin{tabular}{|l|l|l|l|}
\hline Domain & $\begin{array}{l}\text { The value of the correlation } \\
\text { coefficient }\end{array}$ & Number & $\begin{array}{l}\text { Level of statistical } \\
\text { significance }\end{array}$ \\
\hline Social & 0.34 & 638 & $0.001^{*}$ \\
\hline Profile & 0.30 & 638 & $0.005^{*}$ \\
\hline Administrative & 0.41 & 638 & $0.0000^{*}$ \\
\hline
\end{tabular}

Clear from the above table that the correlation coefficient in the social sphere was $(0.34)$, a statistically significant value at the significance level $(\alpha \leq 0,05)$, the correlation coefficient in the personal side has reached (0.30), a statistically significant value when the level of significance $(\alpha \leq 0,05)$, the correlation coefficient in the administrative side has reached $(0.41)$, a statistically significant value at the significance level $(\alpha \leq 0,05)$

Third, the results for the second hypothesis:

This hypothesis has stipulated: "There are no statistically significant differences in the relationship between the leader worker attributes differences with youth and achievement motivation among members due to the variable sex.

The members of this hypothesis has been used ( $g$ ) to make sure that gender differences in the relationship between the leader working with the youth attributes and achievement motivation as perceived by members after converting the correlation coefficients values to the corresponding values, (g) standard Alfsharih, as shown in Table No. (6).

Value ( $\mathrm{g}$ ) of the differences between the characteristics of the leader with the youth factor correlation coefficients as perceived by members and achievement motivation by sex

\begin{tabular}{|l|c|l|l|l|}
\hline Gender & field & number & value $(\mathrm{g})$ & $\begin{array}{l}\text { Alfsharih value } \\
(\mathrm{g})\end{array}$ \\
\hline Social Features & males & 366 & 0.391 & 0.725 \\
\cline { 2 - 4 } & females & 272 & 0.333 & \\
\hline \multirow{2}{*}{$\begin{array}{l}\text { Personal } \\
\text { Features }\end{array}$} & males & 366 & 0.271 & \multirow{2}{*}{0.738} \\
\cline { 2 - 4 } $\begin{array}{l}\text { Administrative } \\
\text { Features }\end{array}$ & females & 272 & 0.330 & \multirow{2}{*}{1.74} \\
\cline { 2 - 4 } & males & 366 & 0.508 & \\
\hline
\end{tabular}

- value (g) Grandpa Les (1.96).

Note from Table (7): there were no statistically significant differences between correlation coefficients in the field of social features differences, personal, administrative and achievement motivation due to the sex of individuals.

Fourth, the results relating to the third hypothesis: 


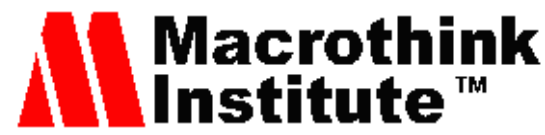

Hypothesis has stipulated no predictive ability: "What is the predictive ability of the characteristics of working with young people (effective leader) to predict the degree of achievement motivation among members".

To answer this question is to use multiple regression method to indicate the extent of the contribution of the social attributes of an effective leader, and personal and administrative predict achievement motivation, Members Table (8) shows that.

The results of multiple regression analysis to measure the ability of the leader with the youth worker attributes to predict the degree of achievement motivation among members.

\begin{tabular}{|l|l|l|l|l|l|}
\hline Statistical & $\begin{array}{l}\text { significance } \\
\text { value }\end{array}$ & $\begin{array}{l}\text { In } \\
\text { contrast }\end{array}$ & $\begin{array}{l}\text { Link } \\
\text { R2 }\end{array}$ & $\begin{array}{l}\text { Multi-coefficient } \\
\text { R }\end{array}$ & $\begin{array}{l}\beta \\
\text { variables }\end{array}$ \\
\hline $\begin{array}{l}\text { social sphere } \\
\text { constant }\end{array}$ & 0.007 & 6.17 & 0.040 & 0.034 & $\begin{array}{l}2.69 \\
82.69\end{array}$ \\
\hline $\begin{array}{l}\text { social sphere } \\
\text { profile sphere } \\
\text { constant }\end{array}$ & 0.003 & 5.96 & 0.071 & 0.027 & 2.91 \\
\hline $\begin{array}{l}\text { social sphere } \\
\text { profile sphere } \\
\text { administrative } \\
\text { sphere } \\
\text { constant }\end{array}$ & 0.001 & 6.77 & 0.125 & 0.039 & 0.87 \\
& & & & & 65.87 \\
\hline
\end{tabular}

Seen from the table (7) that there is the ability to predict the characteristics of an effective leader and their relationship to achievement motivation. As it can be seen from the table that the amount of variation interpreter was $(4 \%)$ in the social sphere and reached $(3 \%)$ in the domain profile, as well (5.4\%) in the administrative area. It is clear from the table that all areas combined: (social, personal and administrative domain) have the ability to interpret achievement motivation among members of a degree (12.5\%) which is statistically significant.

Discuss the search results

First, discuss the results relating to the first hypothesis:

We have provided for the hypothesis: unite statistically significant relationship between social attributes of an effective leader, and personal and administrative as perceived by members and achievement motivation do they have?

To answer this question and given the Table (3), which deals with the social aspect, it is clear that members of the study sample responses on the paragraphs of this area was characterized as high as focused their responses on the paragraphs that describe the behavior of a leader who is working on strengthening, and encouraging members of his team and linking relations with them social based on mutual respect, and understanding of social needs of appreciation for their efforts, and work to consolidate the team spirit and cooperation among themselves, which lead to possess and develop effective and persuasive communication skills in the process of human communication among the leaders themselves and members, The importance of social activities that provide service to the community where the exchange of experiences with the 
leaders on the one hand, leaders and members on the other hand, and this leads to reinforce positive behaviors of the members. All these behaviors driving to accomplish, and a female interrogator for the same and that the young people at this stage any organic age stage in youth centers between 12-18 years old in desperate need of behaviors mentioned above and by which it becomes commander source of confidence and admiration from members due to give them the opportunity to tender and express themselves through activities, and works to direct them and guide them pictures of literary far from acceptable repression and punishment as the philosophy of youth centers include a large part of these practices for personal and promising youth. It has reached the value of the correlation coefficient (0.34) as shown in the table (6), a high value This is necessary as the qualities of social successful leader and deal Democratic soft works to pay members of his team to work and accomplish the tasks required of them in the most efficient image This is consistent with results of a study (Stogdill, 1974 \& Woro, 1994 \& Cornell, 1996)

The results of those studies were unanimous on the positive correlation between an effective leader attributes and achievement motivation of individuals associate.

With regard to the personal aspect it is evident from Table (4) The average single out the study sample responses to the paragraphs of this area was high and amounted to (3.17). This indicates that personality traits such as respect for the leader for his work and belonging to him, calm and self-control, honesty and sincerity in dealing with members, and enjoys the confidence of the same high, and respect for the views of the members and their suggestions, and speak in a clear voice and the concept of, and confidence in the capabilities of the members of his team, and patience and flexibility are necessary and important to raise the achievement motive members.

Balanced Valchksah which has in dealing with young people and has enough experience to know the age characteristics of each stage thus lead to inculcate the optimal values of the member, and this was confirmed by the averages in this area and can this result is attributable to the work with young people comes internal motivated by the commander to work with his group which ultimately aims to promote Bjmaath and work to instill in them the values of authentic, by tradition to become their leader and that they approach life. The work of young people under the practice of behaviors commander leads them to work hard and defying the odds and tender and feel that they are promising and Mattah category, and all this has been confirmed by the results associated with the correlation coefficient in the personal side.

The results have shown that there is a direct correlation between document attributes and motivation, as the value of the correlation coefficient (0.30) shown in Table (6) This result has met with the result (Good \& Brophy, 1997). Those studies confirmed that the commander of personal attributes play an important role in pushing urged his team to work at full power and achievement.

The administrative side of the position in the table (6) shows that respondents responses to paragraphs such as encouraging members to take responsibility and to motivate them for the better and encourage members to creativity and innovation, and its contribution to the development of personal members of his team through their participation in various activities that fit their abilities and potential, and respect laws and instructions, and the coordination with the Members of the Iron appropriate times to carry out activities and to identify the needs of members and work to meet them, and to allow the members to participate in appropriate 
activities to their desires and abilities, without discrimination and taking into account security and safety factors, and control the behavior of users and follow-up. A leader does to those roles through the formation of youth committees in the centers, which is working to develop a personal Members which coordinates with the rest of the members how to establish activities, as well as the philosophy of the Supreme Council for Youth include the formation of boards of directors in the centers as these administrative councils divide the roles between the two of President and Vice Chairman and members, where they contribute to the development of plans necessary for members and claim the commander of the center to apply and activities, and this leads to possession of administrative experience in management meetings and to discuss the emerging issues, where they propose appropriate solutions to the obstacles they face during the application activities and all this helps members to creativity and innovation through those meetings, where they have a sense of deepening democratic atmosphere. The commander of the youth coordinator to work to meet them, opening the way for members to participate in activities that they want and commensurate with their abilities and this is reflected in the value of the correlation coefficient, where results indicated the presence of a positive correlation between owning a commander of administrative features and achievement motivation where results showed a positive relationship between owning a commander of administrative features and motivation achievement, as the value of the correlation coefficient $(0.41)$ as shown in Table (6) This result is consistent with the results study (Dickson, 1994) and study (Fiedler, 1968) and the study of srour (1991).

Second, discuss the results for the second hypothesis:

We have provided for the hypothesis: that there are no statistically significant differences in the relationship between the leader worker with young people between the attributes and achievement motivation of members due to the variable gender differences.

Shown in Table No. (7) that there is a similarity in the views bin Members males and females where Del Table (7) that there is no statistically significant differences due to gender differences, this indicates that the commander of one of the attributes in terms of gender. The results show that the higher the degree of correlation between the administrative features and achievement motivation for males was (0.47), while at the female (0.35), while the lowest value of the correlation coefficient for females in the personal side $(0.32)$, while the male counting $(0,27)$. But the differences between those scores were not statistically significant, and this is illustrated in Table (7) ). In the administrative area, which reached its highest value of the correlation coefficient value "G" stood for the differences between the correlation coefficient (1.74) means that both sexes even Characterized as a successful leader from the perspective of subordinates should those features available in it.

This is due to the successful leader attributes regardless of gender should have the skills available until the encouraging members of his team to accomplish, but Zaid tender, and the main reason so that the philosophy of youth centers one, either male or female, as well as training programs posed by the Higher Council for Youth is one programs for leaders male or female and the nature of the activities of practice vary by tendencies and desires and needs and commensurate with sex Members commensurate with the philosophy of youth centers. But the leadership traits of Duty enjoy a common ground with the leaders differ in fact from one center 
to another position depending on the nature or the group agrees with this Alentijhtaatvq study (Throp, 1988).

Third: discuss the results relating to the third hypothesis:

We have provided for the hypothesis: no predictive ability of the characteristics of the leader with the youth factor in predicting the degree of achievement motivation among members.

Previous results have identified in the table (8) that all social spheres, personal and administrative have the ability to predict the motivation Members achievement, and through multiple regression analysis to determine the ability of the personal characteristics of the leader in the prediction of motivation Members achievement reached contrast ratio (12.5\%), Through the results accessible: it turns out that there are important attributes of an effective leader in the three areas. Where you play these areas combined an important role in raising motivation

Members achievement taking into account that there are many other factors that influence the achievement motivation as a preoccupation or selfishness is mired in the subject, or orientation toward achievement, or compression failure.

The Members who receive a high degree of achievement motivation have with distinct social attributes, personal and administrative leaders with evidence that the variation own social domain R2 with administrative and personal area ratio of $(12.5 \%)$ can be attributed to practitioners, leaders of some of the behaviors in social sphere like looking to Members discerning look like and respect and appreciation, and seen them as holders of rights and duties and pursued and its interaction with Members and their parents result in great confidence place as a result of the behavior of the leader and the coming of the member of the center without conflict with his family, is the motivation for achievement, personal Valslukiat practice by leaders and members of his attention by offering to help and listen to their opinion, and its ability to deal with Members without tension which provides a comfortable atmosphere, leading to the practice of Members of the activities and fun comfortably and thus is considered a motivation for achievement. These results are focused on personal, social and administrative features combined and its ability to predict the achievement motivation, and, finally, observe the behavior of the commander in of the convening of meetings of the members and follow-up and guidance that develops their leadership aspects of the management side, and the courage and clarification of hazardous aspects in some of the activities and permanent attendance with members of the center during the application activities which leads to confidence Commander and behavior. All these behaviors driving force for the completion of the aforementioned combined Valjoinb lead to high achievement that is a positive relationship between the leadership traits and achievement motivation and this was confirmed by the results of the study.

\section{Recommendations}

Based on the findings of this study, the researcher recommends the following:

1) The leaders working to raise achievement motivation among members by encouraging them and enhancing their behavior. The fact shows that the achievement motivation affected behaviors used by leaders.

2) The need to the attention of the leaders of the importance of providing democratic atmosphere for members and consulted on matters that affect them, and involve them in 


\section{Al Macrothink

decision-making, allowing them by making their attitudes and feelings freely - within specific limits and controls - away from the fear and dread.

3) Researcher recommends focusing on all the attributes and competencies commander example and model, and represents the positions covering all aspects of human life, social and administrative aspects.

4) Holding training sessions and rehabilitation programs for the leaders to show the importance of the attributes that must be available to them.

\section{References}

Alababinh, Mohammed Falah. (1999). The level of achievement motivation at Yarmouk University students and its relationship with some personality traits, unpublished Master Thesis: Yarmouk University - Irbid - Jordan.

Alsyar, Abdul Rahman Ahmad. (1999). Effective leadership, sports culture series, Bahrain Sports Institute, the number of 19.

Cornel, Jago. (1996). Decision Making as a SOCIAL Process: Normative and Descriptive Models of Leader Behavior, P 345-370 in Kalb, D: Rubin, I. and Mcintyre, J (ED) Organization Psychology: Reading on Human Behavior in Organizations, Englewood Cliffs: Prentic Hall .

Gray, J.G, \& Starke, E.A. (1980). Decision Making as a Social process: Norm afire And Model of $\mathrm{J}$.

Higan, Abdul Rahman Ahmad. (1993). Administrative leader, analyzing the psychological and social skills in management, Journal of Public Administration, Saudi Arabia.

Hith, W. (1988). The leader_Manager: Guidentines for action. Columbus, Richland: Battelle press.

Qushtah, Abdel Halim Abbas. (1981). Groups and leadership. The Republic of Iraq, Ministry of Higher Education and Scientific Research.

Sarhan, Mahmoud, \& Hassan Fouad. (2000). Guide young workers with health and social awareness. Oman: Department of the National Library.

Supreme Council for Youth (1997). Youth message, Amman.

Wahid, Ahmed Abdel Latif. (2001). Social Psychology Amman: Dar march for publication and distribution, and printing. 